\title{
ANALISIS PENGARUH BUDAYA ORGANISASI DAN GAYA KEPEMIMPINAN TERHADAP KINERJA PEGAWAI
}

\author{
Imam Rifai ${ }^{1)}$ \\ Eka Sudarusman ${ }^{2)}$ \\ 1)Sekolah Tinggi Ilmu Manajemen YKPN Yogyakarta \\ e-mail: imam03rifai@gmail.com \\ ${ }^{2)}$ Sekolah Tinggi Ilmu Manajemen YKPN Yogyakarta \\ e-mail: ekasud@yahoo.com
}

\begin{abstract}
Organizational culture is a system values and beliefs that are shared by people who interact in an rganization that serves as an identity and as reference behavior to achieve organizatinal goals. One of the success factor of an organization goals is leadership, especially leadership style will determine the perfomance of an organization that is shown on the employees performance. This study tried to assess the relationship of organizational culture and leadership style influence on employee performance. The object of this study were employees in Badan Pemberdayaan Masyarakat, Perempuan, dan Keluaraga Berencana in Magelang district. The result in multiple regression analysis showed that organizational culture and the leadership style have significant positive effect on employee performance either partially ( $t$ test) and simultaneously ( $F$ test)
\end{abstract}

Keyword: organizational culture, leadership style, employee performance

\section{PENDAHULUAN}

Setiap negara bertanggungjawab untuk memberikan pelayanan publik yang terbaik bagi rakyatnya. Untuk itu, negara membangun sistem administrasi yang bertujuan melayani kepentingan rakyatnya. Sistem inilah yang dikenal dengan istilah birokrasi. Birokrasi merupakan salah satu instrumen penting yang ada di tengah masyarakat. Selama ini birokrasi diidentikkan dengan kinerja yang berbelit-belit, lamban, struktur yang tambun, penuh dengan kolusi, korupsi dan nepotisme, serta tidak ada standar yang baku. Hal ini terjadi karena selama ini fenomena tersebut seakan-akan sudah menjadi semacam budaya organisasi yang berlangsung turun-temurun di dalam organisasi pemerintahan. Sehingga hal tersebut akan berdampak terhadap kinerja pegawai yang ada di lingkungan organisasi pemerintah tersebut.

Organisasi pemerintah adalah sebuah organisasi yang mempunyai tujuan untuk melayani masyarakat (public service), mulai dari lapisan masyarakat yang paling bawah sampai masyarakat yang paling atas. Dalam era sekarang ini, banyak tuntutan masyarakat agar pelayanan yang diberikan oleh pemerintah ditingkatkan kualitasnya. Untuk mewujudkan keinginan tersebut tentunya peningkatan kinerja aparat pemerintah sangat dibutuhkan. Usaha meningkatkan kinerja aparat pemerintah bisa diawali dengan membentuk budaya organisasi yang baik.

Budaya organisasi adalah sistem nilai dan kepercayaan yang dianut bersama oleh orang-orang yang berinteraksi dalam suatu organisasi, meliputi struktur organisasi dan 
sistem pengawasan untuk menghasilkan norma-norma perilaku (Fremont E. Kast dan James E. Rosenzweigh, 2002). Menurut Djokosantoso Mulyono (2001), Budaya Organisasi merupakan sistem nilai yang diyakini oleh semua anggota organisasi, yang dipelajari, diterapkan dan dikembangkan secara berkesinambungan, berfungsi sebagai perekat, dan dapat dijadikan acuan berperilaku dalam organisasi untuk mencapai tujuan organisasi yang telah ditetapkan. Nilai dan norma perilaku tersebut menciptakan pendekatan yang digunakan anggota organisasi dalam melaksanakan pekerjaan dan untuk menyelesaikan permasalahan yang dihadapi. Setiap organisasi mempunyai karakteristik atau jati diri yang khas, artinya bahwa setiap organisasi mempunyai kepribadian tersendiri. Secara teoritis, budaya organisasi tidak terlepas dari strategi organisasi, termasuk visi dan misi organisasi itu sendiri (Moeljono \& Sudjadmiko, 2007). Budaya yang kuat merupakan landasan kinerja suatu organisasi. Budaya organisasi yang tercipta dapat berpengaruh terhadap aktivitas kerja dari karyawan sehingga secara langsung mempengaruhi kinerja masing-masing karyawan.

Dalam lingkungan instansi pemerintah dikenal adanya budaya kerja aparatur negara. Sesuai dengan Keputusan Menteri Pendayagunaan Aparatur Negara Nomor 25/KEP/M. PAN/04/2002 tanggal 25 April 2002, budaya kerja aparatur negara dapat dikenali wujudnya dalam bentuk nilai-nilai yang terkandung di dalamnya, institusi atau sistem kerja, serta sikap dan perilaku sumber daya manusia yang melaksanakannya. Sehingga budaya kerja aparatur negara dalam keputusan tersebut dapat diartikan sebagai sikap dan perilaku individu dan kelompok aparatur negara yang didasari atas nilai-nilai yang diyakini kebenarannya dan telah menjadi sifat atau kebiasaan dalam melaksanakan tugas pekerjaan sehari-hari. Budaya kerja aparatur negara diharapkan akan bermanfaat bagi pribadi yang bersangkutan maupun unit kerjanya, dimana secara pribadi memberi kesempatan berperan, berprestasi dan aktualisasi diri, sedangkan bagi kelompok dapat berperan meningkatkan kualitas kinerja bersama.

Setiap karyawan dalam organisasi harus memiliki komitmen yang tinggi terhadap pencapaian visi, misi dan tujuan organisasi. Dalam organisasi sektor publik, ikatan batin antara karyawan dan organisasi dapat dibangun dari kesamaan visi, misi dan tujuan organisasi bukan sekedar ikatan kerja. Jadi ikatan pegawai yang bekerja di instansi pemerintah bukan sekedar karena gaji, namun lebih pada ikatan batin misalnya ingin menjadi abdi negara dan abdi masyarakat sehingga jika setiap pegawai mempunyai komitmen yang kuat untuk memberikan prestasi terbaik bagi negara dan pelayanan terbaik bagi masyarakat, maka kinerja sektor publik akan meningkat.

Setiap organisasi pada umumnya percaya untuk mencapai keunggulan bersaing, maka harus mengusahakan kinerja individual yang setinggi-tingginya, karena pada dasarnya kinerja individual akan mempengaruhi kinerja tim atau kelompok yang pada akhirnya akan mempengaruhi kinerja organisasi secara keseluruhan.

Salah satu faktor keberhasilan suatu organisasi mencapai tujuannya adalah kepemimpinan. Suatu organisasi membutuhkan seorang pimpinan yang mempunyai kemampuan untuk mempengaruhi perilaku anggotanya. Jadi, seorang pemimpin akan diakui sebagai seorang pimpinan yang berhasil apabila ia dapat mempunyai pengaruh dan mampu mengarahkan anggotanya kearah pencapaian tujuan organisasi.

Menurut Gibson dalam Nurjanah (2008), kepemimpinan didefinisikan sebagai kemampuan menggunakan pengaruh dan memotivasi individu untuk mencapai tujuan organisasi. Hal ini mengandung konsekuensi bahwa seorang pemimpin mempunyai otoritas untuk merencanakan, menggerakkan, mengarahkan semua potensi yang ada pada anggotanya dalam usaha mencapai tujuan organisasi. 
Kualitas dari seorang pemimpin merupakan faktor terpenting yang akan menentukan keberhasilan atau kegagalan sebuah organisasi (Menon dalam Nurjanah, 2008). Ketika pimpinan bisa menunjukkan sikap dan perilaku kepemimpinan yang baik, para anggotanya akan cenderung mudah menerima petunjuk dan arahan dari pimpinannya sehingga usaha mencapai tujuan organisasi akan lebih mudah tercapai.

Dalam organisasi publik atau pemerintahan, pemimpin memegang peranan yang sangat strategis karena bawahan cenderung bekerja selalu tergantung dengan pimpinannya. Apabila pimpinan tidak memiliki kemampuan memimpin yang baik, maka tugas dan pekerjaan bawahan tidak akan berjalan dengan baik. Berhasil tidaknya sebuah organisasi publik menjalankan tugasnya sangat bergantung dari kualitas pimpinannya,.

Kinerja menurut Prawirosentono (2000) adalah hasil kerja yang dapat dicapai seseorang atau sekelompok orang dalam suatu organisasi, sesuai dengan wewenang dan tanggung jawabnya masing-masing untuk mencapai tujuan organisasi yang bersangkutan secara legal, tidak melanggar hukum, dan sesuai dengan moral dan etika. Penilaian kerja pada karyawan biasanya didasarkan pada job description yang telah disusun oleh organisasi. Dengan demikian, baik buruknya kinerja karyawan dapat dilihat dari kemampuannya dalam melaksanakan tugas pokok dan fungsinya sesuai dengan pekerjaan yang menjadi tanggung jawabnya.

Dalam Kep. Menpan 25/KEP/M.PAN/04/2002 dijelaskan mengenai keadaan aparatur negara saat ini, antara lain:

1. Banyaknya sorotan masyarakat terhadap profesionalisme aparatur negara menandakan masyarakat belum puas terhadap pelayanan yang diberikan oleh aparatur negara.

2. Pemimpin masih menunjukkan sikap sebagai seorang "birokrat feodal" yang menuntut bawahannya untuk selalu setia dan loyal menuruti segala perintah dan keinginannya sehingga menumbuhkan karakter bawahan yang Asal Bapak Senang (ABS).

3. Dedikasi dan loyalitas aparatur negara masih rendah, bahkan masih banyak yang salah menerapkan loyalitas hanya ditujukan kepada atasan, tapi tidak loyal terhadap visi, misi dan tugas instasinya.

4. Peraturan disiplin dan keteraturan kerja sudah dituangkan dalam prosedur-prosedur kerja yang lengkap, tetapi belum dilaksanakan secara optimal, baru sebatas formalitas belum dilakukan secara nyata.

5. Belum ada standar penilaian kinerja yang jelas sehingga sulit untuk mengukur kinerja pegawai secara obyektif dan tindak lanjut hasil penilaiannya.

6. Kurangnya kesadaran aparatur negara untuk meningkatkan integritas dan profesionalisme pribadi melalui peningkatan kompetensi yang sesuai dengan perkembangan ilmu pengetahuan dan teknologi.

Beberapa contoh kasus diatas menunjukkan bahwa kinerja aparatur pemerintah selama ini belum optimal. Pada era globalisasi sekarang, sebuah organisasi dituntut harus mempunyai kinerja yang tinggi agar dapat bertahan di tengah-tengah persaingan global yang sangat ketat. Sehingga kualitas gaya kepemimpinan dan budaya organisasi yang positif sangat diperlukan untuk meningkatkan kinerja karyawannya.

Badan Pemberdayaan Masyarakat, Perempuan dan Keluarga Berencana (BPM PKB) Kabupaten Magelang merupakan instansi pendukung tugas Bupati di bidang pemberdayaan masyarakat, pemberdayaan perempuan, perlindungan anak dan keluarga berencana. Instansi ini mempunyai visi terwujudnya peningkatan kualitas sumber daya 
manusia dan kehidupan beragama melalui pemberdayaan masyarakat, pemberdayaan perempuan, perlindungan anak, penguatan keluarga sejahtera, kelembagaan desa, keluarga berencana dan keluarga sejahtera.

Penelitian ini mengkaji tentang pengaruh budaya organisasi dan gaya kepemimpinan terhadap kinerja pegawai di lingkungan BPM PKB Kabupaten Magelang. Secara lebih rinci, penelitian ini mengkaji tentang 1) pengaruh budaya organisasi terhadap kinerja pegawai di BPM PKB Kabupaten Magelang; 2) pengaruh gaya kepemimpinan terhadap kinerja pegawai di BPM PKB Kabupaten Magelang, dan 3) seberapa besar pengaruh budaya organisasi dan gaya kepemimpinan terhadap kinerja pegawai di BPM PKB Kabupaten Magelang.

Berdasarkan uraian tersebut, diajukan hipotesis sebagai berikut:

H1: Budaya organisasi berpengaruh positif dan signifikan terhadap kinerja pegawai di BPM PKB Kabupaten Magelang.

H2: Gaya kepemimpinan berpengaruh positif dan signifikan terhadap kinerja pegawai di BPM PKB Magelang.

H3: Semakin baik kepemimpinan yang diterapkan dan didukung dengan budaya organisasi yang kondusif maka semakin tinggi kinerja pegawai di BPM PKB Kabupaten Magelang.

\section{KAJIAN TEORI}

\section{Budaya Organisasi}

Istilah budaya berasal dari bahasa sansekerta budhayah bentuk jamak dari kata dasar budhi, yang artinya akal atau segala sesuatu yang berkaitan dengan akal pikiran, nilai-nilai dan sikap mental (Kepmenpan No.25/KEP/M.PAN/04/2002). Menurut Robbins dalam Nurjanah (2008), budaya diartikan sebagai seperangkat perilaku, perasaan, dan kerangka psikologis yang terinternalisasi sangat mendalam dan dimiliki bersama oleh anggota organisasi. Budaya juga dapat diartikan sebagai pola asumsi dasar yang diciptakan, ditemukan atau dikembangkan oleh kelompok tertentu sebagai pembelajaran untuk mengatasi masalah adaptasi eksternal dan integrasi internal yang resmi dan terlaksana dengan baik dan oleh karena itu diajarkan/diwariskan kepada anggota-anggota baru sebagai cara yang tepat untuk memahami, memikirkan dan merasakan terkait dengan masalah-masalah itu.

Budaya bersifat sosial dalam arti penerusan tradisi sekelompok manusia yang dari segi materialnya dialihkan secara historis dan diserap oleh generasi-generasi menurut nilai-nilai yang berlaku. Nilai di sini adalah ukuran-ukuran tertinggi bagi perilaku manusia. Suatu budaya yang kuat merupakan perangkat yang sangat bermanfaat untuk mengarahkan perilaku guna membantu karyawan untuk melakukan pekerjaan dengan lebih baik. Untuk itu setiap karyawan perlu mempelajari dan memahami budaya dalam suatu organisasi serta budaya tersebut terimplementasikan.

Menurut Nurjanah (2008), organisasi merupakan kesatuan yang diorganisasikan secara sadar, dengan sebuah batasan yang relatif dapat diidentifikasikan, bekerja secara terus-menerus untuk mencapai tujuan. Menurut Sukanto dan Handoko (2000), organisasi adalah perserikatan orang-orang yang masing-masing diberi peranan tertentu dalam suatu sistem kerja dan pembagian kerja dimana pekerjaan itu diperinci menjadi tugas-tugas, dibagikan di antara pemegang peranan dan kemudian digabung kedalam berbagai bentuk hasil. 
Menurut Gering Supriyadi dan Tri Guno (2006), terdapat dua pengertian organisasi yaitu: organisasi dalam arti statis dan organisasi dalam arti dinamis. Organisasi dalam arti statis merupakan wadah yang berupa struktur/bagan organisasi, tempat berkumpulnya orang-orang/anggota yang melaksanakan tugas dalam mencapai tujuan organisasi. Sedangkan organisasi dalam arti dinamis merupakan suatu proses penetapan dan pembagian pekerjaan bagi anggota-anggotanya guna memudahkan pencapaian tujuan bersama.

Berdasarkan beberapa pengertian diatas, dapat disimpulkan organisasi merupakan sekumpulan orang yang bekerja sama dengan pembagian dan alokasi tugas dan tanggung jawab tertentu dalam sistem koordinasi dan pengaturan untuk memudahkan pencapaian tujuan yang telah ditetapkan.

Setiap organisasi mempunyai karakteristik atau jati diri yang khas membentuk kepribadian tersendiri sehingga membedakan antara suatu organisasi dengan organisasi lainnya. Hal inilah yang disebut dengan budaya organisasi. Organisasi yang memiliki budaya yang kuat akan memiliki ciri khas tertentu yang dapat memberikan daya tarik bagi individu untuk bergabung di dalamnya.

Budaya organisasi sering diartikan sebagai nilai-nilai, simbol-simbol yang dimengerti dan dipatuhi bersama, yang dimiliki suatu organisasi sehingga anggota organisasi merasa satu keluarga dan menciptakan suatu kondisi yang berbeda dengan organisasi lain.

Menurut Nurjanah (2008) budaya organisasi mempunyai sejumlah karakteristik penting, diantaranya:

1. Aturan perilaku yang diamati

Ketika anggota organisasi berinteraksi satu sama lain, mereka menggunakan bahasa, istilah, dan ritual-ritual tertentu yang hanya dipahami anggota organisasi tersebut.

2. Norma

Adalah standar perilaku, mencakup pedoman mengenai seberapa banyak pekerjaan yang dilakukan.

3. Nilai dominan

Organisasi mendukung dan berharap dari anggota organisasi bisa memberikan kualitas kinerja terbaiknya bagi organisasi.

4. Filosofi

Terdapat kebijakan yang membentuk kepercayaan organisasi mengenai bagaimana karyawan atau pelanggan diperlakukan.

5. Aturan

Terdapat pedoman ketat berkaitan dengan pencapaian perusahaan. Setiap anggota harus mampu menyesuaikan diri dengan pedoman/aturan yang ada agar dapat diterima di dalam sebuah organisasi.

6. Iklim organisasi

Merupakan keseluruhan perasaan yang disampaikan dengan pengaturan baru yang bersifat fisik, cara anggota organisasi berinteraksi dengan sesama anggota maupun dengan pihak luar.

Budaya organisasi terbentuk begitu satuan kerja atau organisasi itu berdiri, menurut Ndraha (2003) menjelaskan pembentukan budaya kerja terjadi tatkala lingkungan kerja atau organisasi menghadapi masalah, baik yang menyangkut perubahan-perubahan eksternal maupun internal yang menyangkut persatuan dan keutuhan organisasi. Pembentukan budaya organisasi diawali oleh para pendiri (founders) atau pimpinan paling atas (top management) dimana besarnya pengaruh yang dimilikinya akan menentukan suatu cara 
tersendiri apa yang dijalankan dalam satuan kerja atau organisasi yang dipimpinnya. Gambar 1 merupakan proses terbentuknya budaya organisasi dalam sebuah satuan kerja atau organisasi.

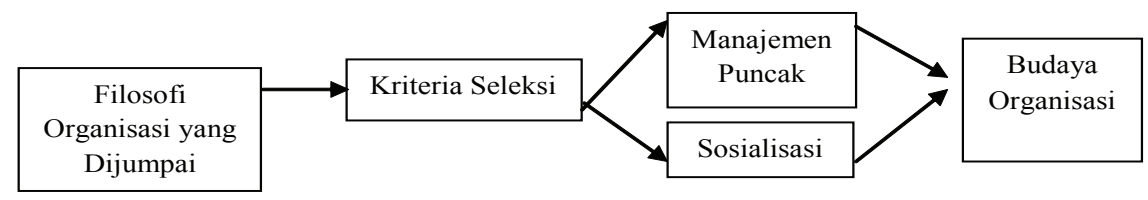

Gambar 1. Proses Terbentuknya Budaya Organisasi

Nurjanah (2008) menjelaskan bagaimana budaya organisasi dibangun dan dipertahankan yang ditunjukkan dari filsafat pendiri atau pimpinannya. Selanjutnya budaya ini sangat dipengaruhi oleh kriteria yang digunakan dalam mempekerjakan pegawai. Tindakan pimpinan akan sangat berpengaruh terhadap perilaku bawahannya untuk dapat diterima di lingkungan tempat kerjanya. Bagaimana bentuk sosialisasi akan tergantung dari kesuksesan yang dicapai dalam menerapkan nilai-nilai dalam proses seleksi. Namun secara perlahan nilai-nilai tersebut akan terseleksi untuk melakukan penyesuaian terhadap perubahan yang pada akhirnya akan muncul sebuah budaya organisasi yang diinginkan.

\section{Gaya Kepemimpinan}

Kepemimpinan merupakan salah satu faktor penting bagi keberhasilan sebuah organisasi untuk mencapai tujuannya. Kepemimpinan didefinisikan secara beragam oleh para ahli namun secara umum kepemimpinan menggambarkan hubungan antara pimpinan (leader) dengan yang dipimpin (follower).

Kepemimpinan menurut Siagian (2002) adalah kemampuan seseorang untuk mempengaruhi orang lain dalam hal ini para bawahannya sedemikian rupa sehingga orang lain itu mau melakukan kehendak pemimpin meskipun secara pribadi hal itu mungkin tidak disenangi. Rakhmat Nugroho (2006) lebih lanjut menjelaskan kepemimpinan mengandung makna pemimpin mempengaruhi yang dipimpin tapi hubungan pemimpin dan yang dipimpin bersifat saling menguntungkan kedua belah pihak.

Kepemimpinan yang efektif akan mampu memberikan motivasi bagi anggota organisasi untuk meningkatkan produktivitas, loyalitas dan kinerjanya. Seorang pemimpin dapat memberikan pengaruh dan merubah perilaku anggotanya melalui gaya kepemimpinan yang dimilikinya. Orang-orang yang bekerja untuk gaya kepemimpinan tertentu, termotivasi untuk berusaha dan bekerja lebih keras karena menyukai dan menghargai gaya kepemimpinan dari pemimpin tersebut.

Gaya kepemimpinan (leadership styles) merupakan cara pimpinan untuk mempengaruhi orang lain atau bawahannya sehingga orang tersebut mau melakukan kehendak pemimpin untuk mencapai tujuan organisasi. Nurjanah (2008). Menurut Tampubolon (2007) gaya kepemimpinan adalah perilaku dan strategi sebagai hasil kombinasi dari falsafah, keterampilan, sifat, dan sikap yang diterapkan oleh seorang pemimpin ketika ia mencoba mempengaruhi kinerja bawahannya.

Dalam teori jalur tujuan (Path Goal Theory) yang dikembangkan oleh Kreitner dan Kinicki (2005) menyatakan bahwa pemimpin mendorong kinerja lebih tinggi dengan cara memberikan kegiatan-kegiatan yang mempengaruhi bawahannya agar percaya bahwa hasil yang berharga bisa dicapai dengan usaha yang lebih serius. Kepemimpinan yang 
berlaku secara universal menghasilkan tingkat kinerja dan kepuasan bawahan yang lebih tinggi.

Dalam perkembangannya ada dua konsep kepemimpinan yang berkembang dan mendapat perhatian banyak kalangan akademisi dan praktisi yaitu konsep transaksional (transactional leadership) dan konsep tranformasional (transformational leadership). Menurut Rakmat Nugroho (2006) konsep ini mampu mengakomodir konsep kepemimpinan secara luas, termasuk pendekatan perilaku, pendekatan situasional sekaligus pendekatan kontingensi. Oleh karena itu, penelitian ini memusatkan pembahasan pada kedua konsep ini.

Menurut Rakhmat Nugroho (2006), penjelasan mengenai konsep kepemimpinan transaksional dan transformasional adalah sebagai berikut:

1. Kepemimpinan Transaksional (transactional leadership)

Kepemimpinan transaksional (transactional leadership) mendasarkan diripada prinsip transaksi atau pertukaran antara atasan dan bawahan. Pimpinan memberikan imbalan atau penghargaan tertentu kepada bawahan jika mampu berprestasi dan memenuhi harapan pimpinan. Di sisi lain, bawahan berusaha untuk mendapatkan prestasi yang baik dan berupaya untuk memenuhi harapan pimpinan agar bisa mendapatkan imbalan atau penghargaan tersebut. Sehingga tercipta suatu hubungan mutualisme (saling menguntungan) dan kontribusi kedua belah pihak akan memperoleh imbalan. Kebutuhan fisik dan materi bawahan berusaha dipenuhi oleh pimpinan dan sebagai balasannya pimpinan akan memperoleh imbalan berupa kinerja dan performa yang tinggi dari bawahan.

Kepemimpinan transaksional menurut beberapa pakar memiliki dua karakter yang dinamakan contingentreward dan management by exception. Pemimpin transaksional yang mempunyai karakter contingent reward akan menjelaskan tujuan dan sasaran yang hendak dicapainya dan mengarahkan bawahan untuk mencapainya. Besar kecilnya imbalan (reward) akan tergantung pada (contingent) sejauhmana bawahan mencapai tujuan dan sasaran tersebut (Bass, 2003).

Sedangkan pemimpin transaksional berkarakter management by exception dapat dibagi lagi kedalam dua sifat, yaitu aktif dan pasif. Pada active management by exception, pemimpin menetapkan tujuan dan sasaran yang hendak dicapai berikut standar kerja yang harus dipatuhi. Jika terjadi penyimpangan, pemimpin tidak segan menjatuhkan sanksi kepada bawahan. Pemimpin dengan sifat seperti ini akan cenderung mengawasi bawahan dengan ketat dan segera melakukan tindakan korektif apabila muncul penyimpangan atau kesalahan.

Sementara pada passive management by exception, pemimpin menghindari tindakan korektif atau "keributan" dengan bawahan selama tujuan dan sasaran yang disepakati bersama tercapai.

2. Kepemimpinan Transformasional (transformational leadership)

Kepemimpinan Transformasional (transformational leadership) lebih mendasarkan diri pada prinsip pengembangan bawahan (follower development). Konsep ini menjelaskan bahwa hubungan antara atasan dengan bawahan lebih dari sekedar pertukaran "komoditas" (pertukaran imbalan secara ekonomis), tapi sudah menyentuh sistem nilai (value system). Pemimpin transformasional mampu menyatukan seluruh bawahannya dan mampu mengubah keyakinan (beliefs), sikap, dan tujuan pribadi masing-masing bawahan demi mencapai tujuan, bahkan melampaui tujuan yang ditetapkan. Dalam konsep ini menjelaskan kemampuan pemimpin 
transformasional mengubah sistem nilai bawahan demi mencapai tujuan diperoleh dengan mengembangkan salah satu atau seluruh faktor yang merupakan dimensi kepemimpinan transformasional, yaitu: karisma (kemudian diubah menjadi pengaruh ideal atau idealized influence), inspirasi (inspirational motivation), pengembangan intelektual (intellectual stimulation), dan perhatian pribadi (individualized consideration).

Berdasarkan beberapa definisi tentang gaya kepemimpinan di atas, dapat disimpulkan bahwa gaya kepemimpinan merupakan kemampuan dari seorang pemimpin dalam mengarahkan, mempengaruhi, mendorong, dan mengendalikan bawahannya untuk melakukan pekerjaan sesuai dengan kehendak pimpinannya yang bertujuan untuk mencapai tujuan organisasi.

\section{Kinerja Karyawan}

Kinerja merupakan suatu kondisi untuk mengetahui tingkat pencapaian hasil suatu instansi dihubungkan visi, misi dan tujuan dari organisasi. Istilah kinerja berasal dari kata prestasi kerja (performance) atau presatasi sesungguhnya yang dicapai oleh seseorang (Actual Performance). Pengertian kinerja adalah hasil kerja secara kualitas dan kuantitas yang dicapai oleh seseorang karyawan dalam melaksanakan tugasnya sesuai dengan tanggung jawab yang diberikan kepadanya.

Sebagaimana dikemukakan oleh Mangkunegara (2005) bahwa kinerja karyawan merupakan salah suatu ukuran yang dapat digunakan untuk menetapkan perbandingan hasil pelaksanaan tugas, tanggung jawab yang diberikan oleh organisasi pada periode tertentu dan relatif dapat digunakan untuk mengukur prestasi kerja atau kinerja organisasi.

Menurut Mariam (2009), menyebutkan ada 6 (enam) kriteria yang dapat digunakan untuk mengukur kinerja pegawai secara individu, yaitu:

1. Kualitas

Hasil pekerjaan yang dilakukan mendekati sempurna atau memenuhi tujuan yang diharapkan dari pekerjaan tersebut.

2. Kuantitas

Jumlah yang dihasilkan atau jumlah aktivitas dari pekerjaan yang dilakukan.

3. Ketepatan waktu

Penyelesaian pekerjaan pada waktu yang telah ditetapkan serta dapat memaksimalkan waktu yang tersedia untuk aktivitas yang lain.

4. Efektivitas

Pemanfaatan secara maksimal sumber daya yang ada dalam organisasi untuk meningkatkan keuntungan dan menghindari kerugian.

5. Kemandirian

Dapat melaksanakan tugas pekerjaan sendiri untuk pekerjaan-pekerjaan yang sudah menjadi tanggung jawabnya.

6. Komitmen kerja

Komitmen untuk bekerja secara maksimal dan mempunyai rasa tanggung jawab terhadap organisasinya.

Berdasarkan pengertian dari beberapa pendapat diatas dapat disimpulkan kinerja merupakan perbandingan hasil kerja yang dicapai seseorang baik secara kuantitas maupun kualitas dengan standar yang telah ditentukan di dalam suatu organisasi. Kinerja umumnya diposisikan sebagai variabel dependen dalam penelitian-penelitian empiris karena dipandang sebagai dampak atau akibat dari perilaku organisasi. 


\section{Hubungan antara Budaya Organisasi dan Kinerja Karyawan}

Pada dasarnya setiap orang yang berada dalam sebuah organisasi berusaha untuk membentuk dan menentukan sesuatu yang dapat mengakomodasi kepentingan semua pihak agar dapat menjalankan aktivitasnya. Sejauh mungkin sesuatu yang diharapkan tersebut tidak berbenturan dengan sikap dan perilaku dari masing-masing individu. Sesuatu yang dimaksud adalah budaya yang terbentuk dari nilai, keyakinan, anggapan, harapan dan sebagainya.

Menurut Kreitner dan Kinicky (2005) budaya organisasi merupakan nilai keyakinan bersama yang mendasari identitas perusahaan. Menurut Erni R. Ernawan (2004) budaya organisasi merupakan asset tak berwujud milik dari sebuah perusahaan. Budaya organisasi dianggap sebagai asset yang dapat meningkatkan kinerja organisasi. Dalam hal ini budaya organisasi selalu mempunyai dampak positif terhadap perkembangan sebuah organisasi.

\section{Hubungan antara Gaya Kepemimpinan dan Kinerja Karyawan}

Dalam organisasi kemampuan untuk mempengaruhi, menggerakkan dan mendorong bawahan untuk melakukan sesuatu didasarkan pada kekuasaan yang dimiliki pemimpinnya. Keefektifan seorang pemimpin dalam mempengaruhi pengikutnya, sangat ditentukan oleh seberapa besar seseorang mempunyai kekuasaan. Semakin besar kekuasaan, maka akan semakin mudah bagi seorang pemimpin dalam mempengaruhi pengikutnya.

Dalam upaya mempengaruhi tersebut seorang pemimpin menerapkan gaya yang berbeda-beda dalam setiap situasi. Untuk menerapkan gaya kepemimpinan yang efektif harus diawali dengan mendiagnosis situasi dengan sebaik-baiknya. Situasi berkaitan dengan kapan, tuntutan iklim organisasi, harapan serta kemampuan atasan dan bawahan.

Gaya kepemimpinan merupakan berbagai pola tingkah laku yang disukai oleh pemimpin dalam proses mengarahkan dan mempengaruhi pekerja. Dari pengertian tersebut terungkap bahwa apa yang dilakukan seorang pimpinan mempunyai pengaruh terhadap bawahan. Pengaruh tersebut dapat bersifat positif seperti membangkitkan semangat, motivasi dan kegairahan kerja ataupun dapat bersifat sebaliknya tergantung penerimaan bawahannya terhadap gaya kepemimpinan tersebut.

\section{Penelitian Terdahulu}

Penelitian seperti ini sebelumnya pernah dilakukan oleh Rakhmat Nugroho (2006), dengan judul Analisis Faktor-Faktor Yang Mempengaruhi Kinerja Karyawan pada Bank Tabungan Negara (persero) Cabang Bandung.

Perbedaan penelitian ini dengan penelitian sebelumnya adalah objek penelitian dan fokus bahasan penelitian. Penelitian terdahulu dilakukan di perusahaan swasta dengan bahasan faktor-faktor yang mempengaruhi kinerja karyawan, sedangkan penelitian ini dilakukan di instansi pemerintah dengan fokus bahasan tentang pengaruh budaya organisasi dan gaya kepemimpinan terhadap kinerja pegawai.

Berdasarkan hasil analisis yang dilakukan pada penelitian terdahulu dapat ditarik kesimpulan:

1. Variabel Gaya Kepemimpinan $\left(\mathrm{X}_{1}\right)$ berpengaruh positif dan signifikan terhadap variabel kinerja karyawan $(\mathrm{Y})$ dengan koefisien nilai $\mathrm{t}_{\text {hitung }}$ dari vaiabel $\mathrm{X}_{1}$ memiliki probability significancy $(0,000)$ lebih kecil $0,05(\alpha=5 \%)$, maka Ho ditolak.

2. Variabel Budaya Organisasi $\left(\mathrm{X}_{2}\right)$ berpengaruh positif dan signifikan terhadap variabel kinerja karyawan $(\mathrm{Y})$ dengan koefisien nilai $\mathrm{t}_{\text {hitung }}$ dari vaiabel $\mathrm{X}_{2}$ memiliki probability significancy $(0,000)$ lebih kecil $0,05(\alpha=5 \%)$ atau mendekati nol, maka Ho ditolak. 
3. Terdapat hubungan positif dan signifikan antara $\left(\mathrm{X}_{1}\right)$ dan $\left(\mathrm{X}_{2}\right)$ terhadap $(\mathrm{Y})$ pada Bank BTN Cabang Bandung dengan koefisien determinasi $\mathrm{R}^{2}=0,540$. Hal ini dapat diartikan bahwa $54 \%$ variasi variabel kinerja karyawan (Y) dapat diterangkan oleh variabel Gaya Kepemimpinan $\left(\mathrm{X}_{1}\right)$, Budaya Organisasi $\left(\mathrm{X}_{2}\right)$ dan moderate $\left(\mathrm{X}_{2}^{*} \mathrm{X}_{3}\right)$, sedangkan sisanya (46\%) dipengaruhi variabel lainnya.

\section{METODE PENELITIAN}

\section{Objek Penelitian}

Objek dalam penelitian ini adalah pegawai pada Badan Pemberdayaan Masyarakat, Perempuan dan Keluarga Berencana Kabupaten Magelang.

\section{Jenis dan Sumber Data}

a. Data Primer

Data primer merupakan sumber data penelitian yang diperoleh secara langsung dari sumber asli atau tanpa media perantara. (Sugiyono,2007) Pada penelitian ini data primer diperoleh dari hasil penyebaran kuesioner kepada responden yang telah ditentukan, yaitu pegawai pada Badan Pemberdayaan Masyarakat, Perempuan dan Keluarga Berencana Kabupaten Magelang.

b. Data Sekunder

Menurut Fuad Mas'ud (2004), data sekunder merupakan sumber data penelitian yang diperoleh secara tidak langsung melalui perantara (diperoleh dan dicatat oleh pIhak lain).

Data sekunder dalam penelitian ini adalah data dari Badan Pemberdayaan Masyarakat, Perempuan dan Keluarga Berencana Kabupaten Magelang tentang gambaran umum keadaan instansi yang bersangkutan.

\section{Populasi}

Populasi adalah wilayah generalisasi yang terdiri atas objek/subyek yang mempunyai kualitas dan karakteristik tertentu yang ditetapkan oleh peneliti untuk dipelajari dan kemudian ditarik kesimpulannya (Sugiyono,2007). Populasi dalam penelitian ini adalah pegawai di lingkup Badan Pemberdayaan Masyarakat, Perempuan dan Keluarga Berencana Kabupaten Magelang sejumlah 198 orang.

\section{Sampel}

Sampel adalah bagian dari jumlah dan karakteristik yang dimiliki oleh populasi. Pengambilan sampel dalam penelitian ini menggunakan metode random sampling (probability sampling) dengan teknik simple random sampling. Oleh karena populasi sudah diketahui jumlahnya, maka untuk menentukan jumlah sampel yang akan diteliti menggunakan rumus sebagai berikut (Sugiyono, 2007):

$$
\begin{aligned}
\mathrm{n} & =\frac{\mathrm{N}}{1+\mathrm{Ne}^{2}} \\
\mathrm{n} & =\text { ukuran sampel } \\
\mathrm{N} & =\text { Populasi } \\
\mathrm{e} & =\text { Nilai presisi (misalnya tingkat kepercayaan } 95 \% \text { ) }
\end{aligned}
$$




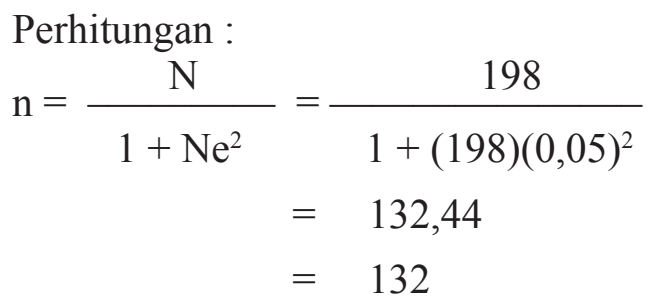

Jadi jumlah sampel dalam penelitian ini adalah 132 pegawai di Badan Pemberdayaan Masyarakat, Perempuan dan Keluarga Berencana Kabupaten Magelang.

\section{Gambaran Objek Penelitian}

Badan Pemberdayaan Masyarakat, Perempuan dan Keluarga Berencana dibentuk berdasarkan Peraturan Daerah Kabupaten Magelang No. 30 Tahun 2008 tentang organisasi dan tata kerja, merupakan unsur pendukung tugas Bupati di bidang Pemberdayaan Masyarakat, Pemberdayaan Perempuan, Perlindungan Anak dan Keluarga Berencana.

Visi dari Badan Pemberdayaan Masyarakat, Perempuan dan Keluarga Berencana Kabupaten Magelang adalah "Terwujudnya peningkatan kualitas sumber daya manusia dan kehidupan beragama melalui Pemberdayaan Masyarakat, Pemberdayaan Perempuan, Perlindungan Anak, Penguatan Keluarga Sejahtera, Kelembagaan Desa, Keluarga Berencana dan Keluarga Sejahtera." Sedangkan misi Badan Pemberdayaan Masyarakat, Perempuan dan Keluarga Berencana Kabupaten Magelang dirumuskan sebagai berikut:

1. Pemantapan pengendalian laju pertumbuhan penduduk.

2. Peningkatan kesadaran masyarakat akan arti pentingnya keluarga sehat dan sejahtera melalui peningkatan program Keluarga Berencana.

3. Peningkatan kesetaraan dan keadilan gender dalam berbagai bidang kehidupan.

4. Penciptaan situasi yang kondusif bagi proses tumbuh kembang anak.

5. Mewujudkan masyarakat yang berbasis komunitas desa yang memiliki kemampuan mengatasi masalah yang ada secara demokratis, transparan dan akuntabel.

\section{Struktur Organisasi}

Sesuai dengan perda no. 30 tahun 2009, Badan Pemberdayaan Masyarakat, Perempuan dan Keluarga Berencana Kabupaten Magelang terdiri dari 1 Kepala Badan, 1 Sekretaris, 4 Kepala Bidang, 3 Kepala Sub. Bagian, 8 Kepala Seksi, 1 Kepala Pusat Pengolah Data, 21 Kepala Balai, 22 Kepala Sub. Bagian TU dan 117 Tenaga Fungsional.

Berdasarkan data kepegawaian dan inventaris Badan Pemberdayaan Masyarakat, Perempuan dan Keluarga Berencana Kabupaten Magelang, jumlah pegawai yang mendukung pelaksanaan tugas pokok dan fungsi sebanyak 198 orang yang terdiri dari 98 laki-laki dan 100 perempuan, dengan tingkat pendidikan S2: 5, S1: 75, D3: 24, SLTA: 88, selebihnya SLTP: 4 dan SD: 1.

\section{Sasaran}

Rencana sasaran yang hendak dicapai oleh Badan Pemberdayaan Masyarakat, Perempuan dan Keluarga Berencana Kabupaten Magelang adalah sebagai berikut:

1. Meningkatnya pengetahuan dan keterampilan masyarakat melalui pelatihanpelatihan.

2. Berkembangnya dan meningkatnya pemanfaatan teknologi tepat guna (TTG).

3. Berkembangnya pasar tradisional/pasar desa dan lembaga usaha ekonomi masyarakat 
4. Menguatkan kelembagaan yang ada dalam pemerintahan masyarakat desa sebagai wadah partisipasi masyarakat.

5. Menurunkan Total Fertility Rate (TFR) menjadi 2,1\%, menurunnya unmet need menjadi $8 \%$, menurunnya DO peserta KB menjadi $3 \%$, meningkatkan peserta KB Pria aktif menjadi $3 \%$, Meningkatnya pendewasaan usia perkawinan, meningkatnya jumlah keluarga sejahtera dan meningkatnya peran institusi masyarakat pedesaan dalam menggerakkan dan mendukung kegiatan pelayanan KB.

\section{Budaya Organisasi di Badan Pemberdayaan Masyarakat Perempuan dan Keluarga Berencana Kabupaten Magelang}

Setiap organisasi mempunyai karakteristik atau jati diri yang khas membentuk sebuah identitas atau kepribadian tersendiri. Identitas atau kepribadian yang khas inilah yang disebut dengan budaya organisasi.

Badan Pemberdayaan Masyarakat Perempuan dan Keluarga Berencana Kabupaten Magelang juga memiliki budaya organisasi tersendiri. Secara umum budaya organisasi yang ada di kantor ini terbentuk dari : sistem kerja, sikap dan karakteristik pimpinan serta pola interaksi diantara pegawai yang ada di dalamnya.

Sistem kerja yang berlaku di Badan Pemberdayaan Masyarakat Perempuan dan Keluarga Berencana Kabupaten Magelang mengacu pada tugas pokok dan fungsi (tupoksi) dari masing-masing pegawai. Jadi setiap pegawai mempunyai tanggung jawab terhadap bidang tugasnya masing-masing. Sistem kerja ini membuat setiap pegawai memiliki kesadaran yang tinggi untuk bisa menyelesaikan tugasnya dengan baik. Pada setiap akhir tahun kinerja dari setiap pegawai akan diberi penilaian melalui DP3 (Daftar Penilaian Pelaksanaan Pekerjaan) yang dilakukan oleh atasan langsung dari pegawai yang bersangkutan.

Sikap dan karakteristik pimpinan pada Badan Pemberdayaan Masyarakat Perempuan dan Keluarga Berencana Kabupaten Magelang juga sangat mempengaruhi budaya organisasi yang ada di dalamnya. Pimpinan mempunyai karakterisitik perfeksionis. Jadi pimpinan menuntut setiap pegawai melakukan tupoksinya secara optimal.

Proses interaksi dari masing-masing pegawai di lingkungan Badan Pemberdayaan Masyarakat Perempuan dan Keluarga Berencana Kabupaten Magelang sangat menjunjung tinggi nilai-nilai kekerabatan dan kekeluargaan. Jadi masing-masing pegawai merasa seperti menjadi sebuah keluarga. Setiap pegawai mempunyai sikap saling menghormati, saling meghargai dan sikap keterbukaan dalam berinteraksi. Masing-masing pegawai juga memiliki jiwa sosial yang tinggi.

\section{Gaya Kepemimpinan pada Badan Pemberdayaan Masyarakat Perempuan dan Keluarga Berencana Kabupaten Magelang}

Gaya kepemimpinan merupakan kemampuan dari seorang pemimpin dalam mengarahkan, mempengaruhi, mendorong, dan mengendalikan bawahannya untuk melakukan pekerjaan sesuai dengan kehendak pimpinannya yang bertujuan untuk mencapai tujuan organisasi. Dalam perkembangannya ada dua konsep kepemimpinan yang berkembang dan mendapat perhatian banyak kalangan akademisi dan praktisi yaitu konsep transaksional (transactional leadership) dan konsep tranformasional (transformational leadership).

Gaya Kepemimpinan pada Badan Pemberdayaan Masyarakat Perempuan dan Keluarga Berencana Kabupaten Magelang cenderung termasuk dalam konsep 
kepemimpinan transaksional (transactional leadership). Hal ini dikarenakan pimpinan mempunyai karakteristik sikap perfeksionis. Pimpinan menginginkan hasil pekerjaan yang optimal dari seluruh bawahannya. Untuk memotivasi para pegawainya, pimpinan memberikan apresiasi kepada pegawai yang berprestasi. Untuk pegawai yang melakukan pelanggaran, pimpinan tidak segan-segan memberikan teguran atau sanksi sesuai dengan aturan yang berlaku.

\section{HASIL DAN PEMBAHASAN}

\section{Gambaran Umum Responden}

Dalam penelitian ini sampel yang diambil sebanyak 132 orang dari 198 karyawan. Data tentang karakteristik responden yang dijadikan sampel adalah sebagai berikut, jumlah responden laki-laki sebanyak 58 orang atau 43,94\% dan responden perempuan sebanyak 74 orang atau $56,06 \%$. Jadi jumlah responden perempuan lebih banyak dibanding dengan responden laki-laki.

Berdasarkan tingkat pendidikan responden terbanyak adalah lulusan Sarjana (S1) sebanyak 71 orang atau 53,79\%. Kemudian diikuti dengan responden lulusan SMA sebanyak 33 orang atau $25 \%$. Selanjutnya responden yang merupakan lulusan Diploma III (D III) sebanyak 23 orang atau 17,42 \%. Urutan berikutnya adalah responden yang merupakan lulusan Pasca Sarjana (S2) sebanyak 4 orang atau 3,03 \%. Sedangkan jumlah responden terkecil merupakan lulusan SMP 1 orang atau $0,76 \%$.

Berdasarkan masa kerja 11-20 tahun sebanyak 57 orang atau 43,18\%, diikuti responden dengan masa kerja 21-30 tahun sebanyak 49 orang atau 37,12\%. Sedangkan responden dengan masa kerja 1-10 tahun sebanyak 26 orang atau 19,70\%. Hal ini menunjukkan pegawai di lingkungan Badan Pemberdayaan, Masyarakat, Perempuan dan Keluarga Berencana Kabupaten Magelang sudah cukup berpengalaman dalam menggeluti bidang pekerjaannya.

\section{Budaya Organisasi}

Pengukuran variabel budaya organisasi dalam penelitian ini menggunakan angket, dengan lima skala jawaban. Setelah skor jawaban angket dari responden diketahui, langkah selanjutnya adalah mencari nilai deskriptif dari jumlah skor tersebut, yang meliputi nilai tertinggi, nilai terendah, standar deviasi dan nilai rata-rata dari variabel budaya organisasi. Hasil analisis deskriptif variabel budaya organisasi selengkapnya dalam tabel sebagai berikut:

Tabel 1. Hasil Analisis Deskriptif Variabel Budaya Organisasi

\begin{tabular}{cccccc}
\hline Variabel & $\mathrm{N}$ & $\begin{array}{c}\text { Nilai } \\
\text { terendah }\end{array}$ & $\begin{array}{c}\text { Nilai } \\
\text { tertinggi }\end{array}$ & $\begin{array}{c}\text { Rata- } \\
\text { rata }\end{array}$ & Standar Deviasi \\
\hline Budaya Organisasi & 132 & 28.00 & 50.00 & 39.95 & 5.147 \\
\hline
\end{tabular}

Sumber: Data primer diolah (2013)

Setelah dibuat stastistik deskriptif, hasil skor jawaban responden secara keseluruhan kemudian dikategorikan menjadi tiga kriteria yaitu baik, cukup dan kurang. Pembagian kategori menggunakan rumus interval kelas yaitu nilai tertinggi ideal dikurangi nilai terendah ideal ditambah satu kemudian dibagi jumlah kelas. Adapun rumus untuk 
mengetahui nilai tertinggi dan terendah sebagai berikut:

1) Nilai tertinggi ideal adalah jumlah angket dikalikan nilai skor tertinggi yaitu: 10 $\mathrm{x}_{5}=50$

2) Nilai terendah ideal adalah jumlah angket dikalikan nilai skor terendah yaitu: 10 $\mathrm{x}_{1}=10$

3) $\quad$ Interval $=\frac{\text { (nilai tertinggi }- \text { nilai terendah })+1}{\text { Jumlah kelas }}$

Interval $=\frac{(50-10)+1=14}{3}$ berikut:

Adapun hasil kategori skor jawaban responden dapat dilihat dalam tabel sebagai

Tabel 2. Distribusi Frekuensi Jawaban Responden Variabel Budaya Organisasi

\begin{tabular}{cccc}
\hline Kriteria Skor & Nilai Interval & Nilai Skor & Prosentase \\
\hline Baik & $38-50$ & 92 & $69.7 \%$ \\
Cukup & $24-37$ & 40 & $30.3 \%$ \\
Kurang & $10-23$ & 0 & $0.0 \%$ \\
\hline Jumlah & & 132 & $100 \%$ \\
\hline
\end{tabular}

Sumber: Data primer diolah (2013)

Berdasarkan distribusi frekuensi skor jawaban responden di atas diketahui bahwa $69,7 \%$ jawaban responden dalam kategori baik dan 30,3\% dalam kategori cukup. Nilai tertinggi jawaban responden adalah dalam kategori baik, menunjukkan bahwa budaya organisasi di Badan Pemberdayaan Masyarakat, Perempuan dan Keluarga Berencana Kabupaten Magelang menurut responden telah mencerminkan orientasi perilaku yang seimbang antara mementingkan karyawan (people oriented) dengan mementingkan tugas (task oriented) untuk mencapai tujuan organisasi melalui pengembangan sumber daya manusia. Hasil analisis deskriptif variabel budaya organisasi dapat digambarkan dalam grafik sebagai berikut.

\section{Gaya Kepemimpinan}

Gaya kepemimpinan dalam penelitian ini diukur melalui kuesioner dengan lima skala jawaban. Setelah skor jawaban angket dari responden diketahui, langkah selanjutnya adalah mencari nilai deskriptif dari jumlah skor tersebut, yang meliputi nilai tertinggi, nilai terendah, standar deviasi dan nilai rata-rata. Hasil analisis deskriptif variabel gaya kepemimpinan selengkapnya dalam Tabel 3.

Tabel 3. Hasil Analisis Deskriptif Variabel Gaya Kepemimpinan

\begin{tabular}{cccccc}
\hline Variabel & $\mathrm{N}$ & $\begin{array}{c}\text { Nilai } \\
\text { terendah }\end{array}$ & $\begin{array}{c}\text { Nilai } \\
\text { tertinggi }\end{array}$ & $\begin{array}{c}\text { Rata- } \\
\text { rata }\end{array}$ & $\begin{array}{c}\text { Standar } \\
\text { Deviasi }\end{array}$ \\
\hline Gaya Kepemimpinan & 132 & 24,00 & 49,00 & 39,33 & 5,22 \\
\hline
\end{tabular}

Sumber: Data primer diolah, 2013 
Setelah dibuat stastistik deskriptif, hasil skor jawaban responden secara keseluruhan kemudian dikategorikan menjadi tiga kriteria yaitu baik, cukup dan kurang. Pembagian kategori menggunakan rumus interval kelas yaitu nilai tertinggi ideal dikurangi nilai terendah ideal ditambah satu kemudian dibagi jumlah kelas. Adapun rumus untuk mengetahui nilai tertinggi dan terendah sebagai berikut:

1) Nilai tertinggi ideal adalah jumlah angket dikalikan nilai skor tertinggi yaitu: 10 $\mathrm{x} 5=50$

2) Nilai terendah ideal adalah jumlah angket dikalikan nilai skor terendah yaitu: 10 $\mathrm{x} 1=10$

3) Interval $=\frac{(\text { nilai tertinggi- } \text { nilai terendah })+1}{\text { Jumlah kelas }}$

$$
\text { Interval }=\frac{(50-10)+1}{3}=14
$$

Adapun hasil kategori skor jawaban responden dapat dilihat dalam Tabel 4.

Tabel 4. Distribusi Frekuensi Jawaban Responden Variabel Gaya Kepemimpinan

\begin{tabular}{cccc}
\hline Kriteria Skor & Nilai Interval & Nilai Skor & Prosentase \\
\hline Baik & $38-50$ & 91 & $68,9 \%$ \\
Cukup & $24-37$ & 41 & $31,1 \%$ \\
Kurang & $10-23$ & 0 & $0,0 \%$ \\
\hline Jumlah & & 132 & $100 \%$ \\
\hline
\end{tabular}

Sumber: Data primer diolah, 2013

Berdasarkan distribusi frekuensi skor jawaban responden di atas diketahui bahwa $68,9 \%$ jawaban responden dalam kategori baik dan 31,1\% dalam kategori cukup. Nilai tertinggi jawaban responden adalah dalam kategori baik, menunjukkan bahwa perilaku dan strategi sebagai hasil kombinasi dari falsafah, keterampilan, sifat serta sikap yang sering diterapkan pimpinan Badan Pemberdayaan Masyarakat, Perempuan dan Keluarga Berencana Kabupaten Magelang dalam mempengaruhi kinerja bawahannya adalah dalam kategori baik. Hasil analisis deskriptif variabel gaya kepemimpinan dapat digambarkan dalam grafik sebagai berikut :

\section{Kinerja Karyawan}

Variabel kinerja karyawan dalam penelitian ini diukur melalui kuesioner dengan lima skala jawaban. Setelah skor jawaban angket dari responden diketahui, langkah selanjutnya adalah mencari nilai deskriptif dari jumlahskor tersebut, yang meliputi nilai tertinggi, nilai terendah, standar deviasi dan nilai rata-rata. Hasil analisis deskriptif variabel kinerja karyawan selengkapnya dalam Tabel 5.

Tabel 5. Hasil Analisis Deskriptif Variabel Kinerja Karyawan

\begin{tabular}{lccccc}
\hline \multicolumn{1}{c}{ Variabel } & $\mathrm{N}$ & $\begin{array}{c}\text { Nilai } \\
\text { terendah }\end{array}$ & $\begin{array}{c}\text { Nilai } \\
\text { tertinggi }\end{array}$ & $\begin{array}{c}\text { Rata- } \\
\text { rata }\end{array}$ & $\begin{array}{c}\text { Standar } \\
\text { Deviasi }\end{array}$ \\
\hline $\begin{array}{l}\text { Variabel Kinerja } \\
\text { Karyawan }\end{array}$ & 132 & 25,00 & 50,00 & 40,91 & 5,13 \\
\hline
\end{tabular}

Sumber: Data primer diolah (2013) 
Setelah dibuat stastistik deskriptif, hasil skor jawaban responden secara keseluruhan kemudian dikategorikan menjadi tiga kriteria yaitu tinggi, sedang dan rendah. Pembagian kategori menggunakan rumus interval kelas yaitu nilai tertinggi ideal dikurangi nilai terendah ideal ditambah satu kemudian dibagi jumlah kelas. Adapun rumus untuk mengetahui nilai tertinggi dan terendah sebagai berikut:

1) Nilai tertinggi ideal adalah jumlah angket dikalikan nilai skor tertinggi yaitu: 10 x $5=50$

2) Nilai terendah ideal adalah jumlah angket dikalikan nilai skor terendah yaitu: 10 $\mathrm{x} 1=10$

3) $\quad$ Interval $=\frac{(\text { nilai tertinggi- nilai terendah })+1}{\text { Jumlah kelas }}$

$$
\text { Interval }=\frac{(50-10)+1}{3}=14
$$

Adapun hasil kategori skor jawaban responden dapat dilihat dalam Tabel 6.

Tabel 6. Distribusi Frekuensi Jawaban Responden Variabel Kinerja Karyawan

\begin{tabular}{cccc}
\hline Kriteria Skor & Nilai Interval & Nilai Skor & Prosentase \\
\hline Tinggi & $38-50$ & 98 & $74,2 \%$ \\
Sedang & $24-37$ & 34 & $25,8 \%$ \\
Rendah & $10-23$ & 0 & $0,0 \%$ \\
\hline Jumlah & & 132 & $100 \%$ \\
\hline
\end{tabular}

Sumber: Data primer diolah (2013)

Berdasarkan distribusi frekuensi skor jawaban responden di atas diketahui bahwa $74,2 \%$ jawaban responden dalam kategori tinggi dan 25,8\% dalam kategori sedang. Nilai tertinggi jawaban responden adalah dalam kategori tinggi, menunjukkan bahwa pegawai di Badan Pemberdayaan Masyarakat, Perempuan dan Keluarga Berencana Kabupaten Magelang selalu melaksanakan tanggung jawab dan tugas kerjanya dengan baik. Hasil analisis deskriptif variabel kinerja karyawan dapat digambarkan dalam grafik sebagai berikut:

\section{Analisis Regresi Berganda}

Analisis regresi berganda dalam penelitian ini digunakan untuk menguji apakah variabel gaya kepemimpinan dan budaya organisasi mempengaruhi kinerja pegawai. Variabel independen dalam penelitian ini adalah budaya organisai $\left(\mathrm{X}_{1}\right)$ dan gaya kepemimpinan $\left(\mathrm{X}_{2}\right)$. Sedangkan variabel dependen adalah kinerja pegawai $(\mathrm{Y})$. Berdasarkan hasil analisis regresi berganda yang telah dilakukan, maka diperoleh hasil pada Tabel 7. 
Tabel 7. Hasil Uji Regresi Linear Berganda

\begin{tabular}{|c|c|c|c|}
\hline Variabel & Konstanta & Budaya Organisasi $\left.\mathbf{( X}_{\mathbf{1}}\right)$ & $\begin{array}{c}\text { Gaya Kepemimpinan } \\
\left(\mathbf{X}_{\mathbf{2}}\right)\end{array}$ \\
\hline Koefisien Regresi & 8,089 & 0,458 & 0,369 \\
\hline T hitung & 3,765 & 4,600 & 3,760 \\
\hline Signifikansi & 0.000 & 0.000 & 0.000 \\
\hline F hitung & \multicolumn{3}{|c|}{118,584} \\
\hline Signifikansi & \multicolumn{3}{|c|}{0.000} \\
\hline R & \multicolumn{3}{|c|}{0.805} \\
\hline R Square & \multicolumn{3}{|c|}{}
\end{tabular}

Hasil analisis regresi diperoleh model persamaan regresi berganda sebagai berikut:

$$
\begin{aligned}
& \mathrm{Y}=\alpha+\beta_{1} \mathrm{X}_{1}+\beta_{2} \mathrm{X}_{2} \mathrm{e} \\
& \mathrm{Y}=8,089+0,458 \mathrm{X}_{1}+0,369 \mathrm{X}_{2} \mathrm{e}
\end{aligned}
$$

Koefisien regresi variabel budaya organisasi sebesar 0,458 dengan nilai probabilitas $0,000<0,05$ yang menunjukkan bahwa ada pengaruh positif dan signifikan antara budaya organisasi terhadap kinerja karyawan. Koefisien regresi bernilai positif, berarti budaya organisasi memiliki arah interaksi positif terhadap kinerja karyawan. Hal tersebut berarti semakin baik budaya organisasi mengakibatkan kinerja karyawan semakin meningkat.

Koefisien regresi variabel gaya kepemimpinan sebesar 0,369 dengan nilai probabilitas $0,000<0,05$ yang menunjukkan bahwa ada pengaruh positif dan signifikan antara gaya kepemimpinan terhadap kinerja karyawan. Koefisien regresi bernilai positif, berarti gaya kepemimpinan memiliki arah interaksi positif terhadap kinerja karyawan. Hal tersebut berarti semakin baik penerapan gaya kepemimpinan mengakibatkan kinerja karyawan semakin meningkat.

\section{Uji Hipotesis}

Uji hipotesis digunakan untuk menguji ketepatan fungsi regresi sampel dalam menaksir nilai aktual, yang terdiri dari uji statistik t, uji statistik F, dan koefesien determinasi.

1. Uji Statistik t

Pengujian ini pada dasarnya menunjukkan seberapa jauh pengaruh satu variabel independen terhadap variabel dependen. Pengujian dilakukan dengan menggunakan significance level 0,05 ( $\alpha=5 \%)$. Berdasarkan hasil analisis statistik t, maka diketahui bahwa:

a. Variabel budaya organisasi diperoleh nilai t hitung sebesar 4,600 dengan nilai signifikansi $0,000<0,05(\alpha=5 \%)$, maka Ho ditolak.

Nilai tersebut menunjukkan bahwa secara parsial variabel budaya organisasi berpengaruh positif dan signifikan terhadap kinerja pegawai.

Berdasarkan analisis regresi linear berganda tersebut maka dapat disimpulkan bahwa:

H1: Budaya organisasi berpengaruh positif dan signifikan terhadap kinerja pegawai di Badan Pemberdayaan Masyarakat, Perempuan dan Keluarga Berencana Kabupaten Magelang dinyatakan diterima dan terbukti kebenarannya. 
Ho: Budaya organisasi tidak berpengaruh positif dan signifikan terhadap kinerja pegawai di Badan Pemberdayaan Masyarakat, Perempuan dan Keluarga Berencana Kabupaten Magelang dinyatakan ditolak.

Hasil penelitian ini mendukung hasil penelitian Rakhmat Nugroho (2006) yang menyatakan bahwa budaya organisasi berpengaruh positif dan signifikan terhadap variabel kinerja karyawan.

b. Variabel gaya kepemimpinan diperoleh nilai t hitung sebesar 3,760 dengan nilai signifikansi $0,000<0,05(\alpha=5 \%)$, maka Ho ditolak. Nilai tersebut menunjukkan bahwa secara parsial variabel gaya kepemimpinan berpengaruh positif dan signifikan terhadap kinerja pegawai.

Berdasarkan analisis regresi linear berganda tersebut maka dapat disimpulkan bahwa:

H2: Gaya kepemimpinan berpengaruh positif dan signifikan terhadap kinerja pegawai di Badan Pemberdayaan Masyarakat, Perempuan dan Keluarga Berencana Kabupaten Magelang dinyatakan diterima dan terbukti kebenarannya.

Ho: Gaya kepemimpinan tidak berpengaruh positif dan signifikan terhadap kinerja pegawai di Badan Pemberdayaan Masyarakat, Perempuan dan Keluarga Berencana Kabupaten Magelang dinyatakan ditolak.

Hasil penelitian ini mendukung hasil penelitian Rakhmat Nugroho (2006) yang menyatakan bahwa gaya kepemimpinan berpengaruh positif dan signifikan terhadap variabel kinerja karyawan.

2. Uji Statistik F

Uji stastistik $\mathrm{F}$ dalam penelitian ini untuk menguji apakah variabel budaya organisasi $\left(\mathrm{X}_{1}\right)$ dan gaya kepemimpinan $\left(\mathrm{X}_{2}\right)$ secara bersama-sama (simultan) berpengaruh terhadap kinerja pegawai (Y). Hasil analisis diperoleh nilai $\mathrm{F}$ hitung sebesar 118,584 dengan tingkat signifikansi 0,000, maka Ho ditolak.

Berdasarkan hasil analisis ini berarti secara simultan variabel independen $\left(\mathrm{X}_{1}\right.$ dan $\mathrm{X}_{2}$ ) tersebut mempunyai pengaruh yang signifikan terhadap variabel dependen $(\mathrm{Y})$. Dengan demikian dapat disimpulkan bahwa:

H3: Semakin baik kepemimpinan yang diterapkan dan didukung dengan budaya organisasi yang kondusif maka semakin tinggi kinerja pegawai di Badan Pemberdayaan Masyarakat, Perempuan dan Keluarga Berencana Kabupaten Magelang dinyatakan dapat diterima dan terbukti kebenarannya

Ho: Budaya organisasi dan gaya kepemimpinan secara simultan tidak mempunyai pengaruh terhadap kinerja dinyatakan ditolak.

Hasil penelitian ini mendukung hasil penelitian Rakhmat Nugroho (2006), bahwa terdapat hubungan positif dan signifikan antara budaya organisasi dan gaya kepemimpinan terhadap kinerja karyawan pada Bank BTN Cabang Bandung.

3. Koefesien Determinasi

Koefesien determinasi $\left(\mathrm{R}^{2}\right)$ pada intinya mengukur seberapa jauh kemampuan model persamaan regresi dalam menerangkan variabel dependen. Hasil analisis regresi linear berganda diperoleh nilai koefisien determinasi $\left(\mathrm{R}^{2}\right)$ sebesar 0,648 . Hal tersebut menunjukkan bahwa besarnya pengaruh budaya organisasi dan gaya kepemimpinan terhadap kinerja karyawan adalah 0,648 atau sebesar 64,8\%. Sisanya sebesar 35,2\% dipengaruhi variabel lain yang tidak diteliti. 


\section{SIMPULAN DAN SARAN}

\section{Simpulan}

Berdasarkan hasil penelitian dan pembahasan yang telah dilakukan, maka dapat disimpulkan bahwa budaya organisasi berpengaruh positif dan signifikan terhadap kinerja pegawai di Badan Pemberdayaan Masyarakat, Perempuan dan Keluarga Berencana Kabupaten Magelang. Hal tersebut diketahui melalui hasil analisis uji t yang diperoleh nilai t hitung sebesar 4,600 dengan nilai signifikansi $0,000<0,05$.

Budaya organisasi merupakan nilai keyakinan bersama yang mendasari identitas dan sebagai asset tak berwujud milik dari sebuah perusahaan. Budaya organisasi yang tidak berbenturan dengan sikap dan perilaku dari masing-masing individu mempunyai dampak positif terhadap kehidupan organisasi. Budaya organisasi yang baik dapat mengakomodasi kepentingan semua pihak dalam menjalankan aktivitasnya sehingga dapat meningkatkan kinerja pegawai di Badan Pemberdayaan Masyarakat, Perempuan dan Keluarga Berencana Kabupaten Magelang.

Gaya kepemimpinan berpengaruh positif dan sigknifikan terhadap kinerja pegawai di Badan Pemberdayaan Masyarakat, Perempuan dan Keluarga Berencana Kabupaten Magelang. Hal tersebut diketahui melalui hasil analisis uji t yang diperoleh nilai t hitung sebesar 3,760 dengan nilai signifikansi $0,000<0,05$. Gaya kepemimpinan merupakan berbagai pola tingkah laku yang disukai oleh pemimpin dalam proses mengarahkan dan mempengaruhi bawahannya. Gaya kepemimpinan yang baik dapat membangkitkan semangat, motivasi dan kegairahan kerja bawahannya sehingga dapat meningkatkan kinerja pegawai di Badan Pemberdayaan Masyarakat, Perempuan dan Keluarga Berencana Kabupaten Magelang.

Hasil penelitian juga membuktikan bahwa budaya organisasi dan gaya kepemimpinan secara simultan berpengaruh terhadap kinerja karyawan. Hal tersebut diketahui melalui hasil analisis uji $\mathrm{F}$ yang diperoleh nilai $\mathrm{F}$ hitung sebesar 118,584 dengan nilai signifikansi $0,000<0,05$. Semakin baik kepemimpinan yang diterapkan dan didukung dengan budaya organisasi yang kondusif maka semakin tinggi kinerja pegawai di Badan Pemberdayaan Masyarakat, Perempuan dan Keluarga Berencana Kabupaten Magelang.

Pengaruh gaya kepemimpinan dan budaya organisasi terhadap kinerja pegawai pada Badan Pemberdayaan Masyarakat, Perempuan dan Keluarga Berencana Kabupaten Magelang sebesar $64,8 \%$, sisanya sebesar $35,2 \%$ dipengaruhi oleh variabel yang tidak diteliti.

\section{Saran}

Berdasarkan hasil penelitian dan kesimpulan yang telah dikemukakan di atas diperoleh bukti empiris bahwa budaya organisasi dan gaya kepemimpinan berpengaruh positif dan signifikan terhadap kinerja pegawai di Badan Pemberdayaan Masyarakat, Pererempuan dan Keluarga Berencana Kabupaten Magelang, maka saran yang diberikan adalah sebagai berikut:

1. Budaya organisasi yang ada di Badan Pemberdayaan Masyarakat, Pererempuan dan Keluarga Berencana Kabupaten Magelang telah mencerminkan orientasi perilakuyang seimbang antara mementingkan karyawan (people oriented) dengan mementingkan tugas (task oriented) serta dapat mengakomodasi kepentingan semua pihak dalam menjalankan aktivitasnya. Hal ini perlu dipertahankan agar kinerja pegawai semakin meningkat sehingga tujuan organisasi dapat tercapai dengan maksimal. 
2. Gaya Kepemimpinan yang diterapkan di Badan Pemberdayaan Masyarakat, Perempuan dan Keluarga Berencana Kabupaten Magelang menunjukkan bahwa perilaku dan strategi sebagai hasil kombinasi dari falsafah, keterampilan, sifat serta sikap yang baik dapat membangkitkan semangat, motivasi dan kegairahan kerja bawahannya. Hal ini perlu dipertahankan agar kinerja pegawai pegawai semakin meningkat sehingga tujuan organisasi dapat tercapai dengan maksimal.

3. Di luar faktor budaya organisasi dan gaya kepemimpinan masih ada faktor-faktor lain yang mempengaruhi kinerja pegawai sebesar 35,2\%. Artinya faktor-faktor lainnya ini juga harus diperhatikan dan perlu diteliti agar kinerja pegawai di Badan Pemberdayaan Masyarakat, Perempuan dan Keluarga Berencana Kabupaten Magelang semakin meningkat.

\section{REFERENSI}

Badan Pemberdayaan Masyarakat, Perempuan dan Keluarga Berencana. 2013. Revisi Renstra. Magelang.

Erni R. Ernawan. 2004. Pengaruh Budaya Organisasi dan Orientasi Etika terhadap Kinerja Perusahaan Manufaktur. Usahawan. September 2008, No.09, Hal: 17-24.

Ghozali, Imam. 2007. Aplikasi Analisis Multivariate dengan Program SPSS. Badan Penerbit Universitas Diponegoro, Semarang.

Kast, Freemont E. dan James E. Rosenzweig. 2002. Organisasi dan Manajemen 2. Bumi Aksara, Jakarta.

Keputusan Menteri Pendayagunaan Aparatur Negara RI Nomor: 25/KEP/M.PAN/04/2002 tentang Pedoman Pengembangan Budaya Kerja Aparatur Negara

Kreiner, Robert dan Kinicky, Angelo. 2005. Perilaku Organisasi Buku 1. Edisi Kelima. Salemba Empat. Jakarta.

Mangkunegara, A.A. Prabu. 2005. Evaluasi Kinerja SDM. Tiga Serangkai, Jakarta.

Mariam, Rani. 2009. Pengaruh Gaya Kepemimpinan Dan budaya Organisasi terhadap Karyawan melalui Kepuasan Kerja Karyawan Sebagai Variabel Intervening. Tesis. Universitas Diponegoro. Semarang.

Mas'ud, Fuad. 2004. Survey Diagnosis Organisasional. Badan Penerbit Universitas Diponegoro, Semarang.

Mulyono, Djokosantoso. 2001. Budaya Korporat dan Keunggulan Korporas. Elex Media Komputindo, Jakarta

Mulyono, Djokosantoso dan Steve Sudjatmiko. 2007. Corporate Culture Challenge to Excellence. Elex Media Komputindo, Jakarta.

Ndraha, Taliziduhu. 2003. Budaya Organisasi, PT Rineka Cipta. Jakarta. 
Nugroho, Rakhmat. 2006. Analisis Faktor-Faktor Yang Mempengaruhi Kinerja Karyawan (Studi Empiris pada BTN Cabang Bandung). Tesis. Universitas Diponegoro. Semarang.

Nurjanah. 2008. Pengaruh Gaya Kepemimpinan Dan Budaya Organisasi Terhadap Komitmen Organisasi Dalam Meningkatkan Kinerja Karyawan (Studi pada Biro Lingkup Departemen Pertanian). Tesis. Universitas Diponegoro. Semarang.

Prawirosentono, Suyadi. 2000. Kebijakan Kinerja Karyawan. BPFE, Yogyakarta.

Sedarmayanti. 2009. Reformasi Publik, Reformasi Birokrasi, dan Kepemimpinan Masa Depan Mewujudkan Pelayanan Prima dan Kepemerintahan yang Baik. Refika Aditama, Bandung.

Siagian, Sondang P. 2002. Kiat Meningkatkan Produktivitas Kerja. Rineka Cipta, Jakarta.

Sugiyono. 2007. Metode Penelitian Bisnis. CV ALFABETA, Bandung.

Sukanto dan T. Hani Handoko. 2000. Organisasi Perusahaan: Teori, Struktur, dan Perilaku. BPFE. Yogyakarta.

Supriyadi, Gering dan Tri Guno. 2006. Budaya Kerja Organisasi Pemerintah. Lembaga Administrasi Negara, Jakarta.

Tampubolon, Biatna. 2007. Analisis Faktor Gaya Kepemimpinan dan Faktor Etos Kerja terhadap Kinerja Pegawai Pada Organisasi yang Telah Menerapkan SNI 199001-2001, Jurnal Standardisas., No.9. Hal: 106-115. 
